\title{
Participatory Rural Appraisal in Increasing Farmers' Awareness of Sprayers against the Use of Personal Protective Equipment in the Tirtomulyo Farmer Group of Lalowosula Village
}

\author{
Habel Pondonggi ${ }^{1 *}$, Erwin Azizi Jayadipraja ${ }^{1}$, Ridwan Adi Surya ${ }^{2}$ \\ ${ }^{\mathrm{T}}$ Mandala Waluya College of Health Sciences, Kendari, Indonesia \\ ${ }^{2}$ Halu Oleo University, Indonesia
}

\section{*Corresponding Author}

Habel Pondonggi

\section{Article History}

Received: 05.03.2020

Accepted: 19.03 .2020

Published: 26.03.2020

\begin{abstract}
The awareness of farmers in using personal protective equipment, when spraying is still very low. So we need a participatory method in increasing the awareness of farmers in using personal protective equipment. The participatory method which proved to be quite significant in raising awareness was the participatory rural appraisal method. The purpose of this study was to determine the effect of participatory rural appraisal in increasing the awareness of spraying farmers on the use of personal protective equipment. This type of research is a pre-experimental design with one group design pre-post test. The population in this study are farmers who are members of the Farmers Group Gapoktan Tirtomulyo Ladongi District as many as 240 farmers. The sample size of 148 respondents was taken by simple random sampling. The results showed that there was an effect of effective participatory rural appraisal methods in increasing farmers' awareness of the use of personal protective equipment, which obtained a p-value $=0,000<\alpha=0.05$. This is because the participatory rural appraisal method can increase farmers' knowledge in remembering or receiving information provided in this case the use of personal protective equipment. The participatory rural appraisal method is effective in increasing farmers' awareness of the use of personal protective equipment. It is expected that related parties can use this method in a wider scope.
\end{abstract}

Keywords: Participatory Rural Appraisal, Farmers, Personal Protective Equipment.

\section{INTRODUCTION}

In general, farmers in Indonesia already know the dangers of using pesticides, but they do not think about the consequences. Many of these farmers do not use Personal Protective Equipment (PPE) such as masks, hats, shoes, and clothing that cover the entire body. Basically, this PPE can help prevent the entry of pesticides into the body through the skin and respiratory tract [1].

Several factors that can affect health conditions and work power include physical, chemical, biological, physiological and mental psychological factors found in the work environment [2]. Farmers' habits in using pesticides sometimes violate the rules, in addition to the dose used exceeds the dose, farmers also often mix several types of pesticides, with the reason to increase the toxicity of plant pests [3]. Such actions are actually very detrimental because they can cause higher levels of pollution in the environment [4].

Impact on health can occur through the skin, breathing, and digestion in the form of acute and chronic poisoning [5]. Symptoms of acute pesticide poisoning, such as headaches, nausea, vomiting, and even some pesticides can cause skin irritation and blindness. In chronic poisoning, it is not easy to detect because its effects are not immediately felt [6].

The incidence of pesticide poisoning in several regions in Indonesia is very high. Based on the results of blood cholinesterase monitoring of 347 workers in agriculture in Central Java it was found $23.64 \%$ of workers were moderate

Copyright @ 2020: This is an open-access article distributed under the terms of the Creative Commons Attribution license which permits unrestricted use, distribution, and reproduction in any medium for non commercial use (NonCommercial, or CC-BY-NC) provided the original author and source are credited. 
poisoning and 35.73 severe poisonings. One example of pesticide poisoning in Indonesia is pesticide poisoning in farmers in Jambi province in 2015. Of the 1320 farmers who used pesticides around $65.2 \%$ experienced poisoning [7].

Based on the results of the study showed that there was a significant relationship between the types of pesticides used ( $\mathrm{p}$-value $=0.021)$, length of work ( $\mathrm{p}$-value $=0.002)$, and frequency of spraying time (hours/day) with $\mathrm{p}$-value $=$ 0.018 with health complaints felt by farmers pesticide sprayer. Pesticide spraying farmers in Berastagi District are at risk of experiencing pesticide poisoning through direct contact due to not using PPE [8].

The results of research on the relationship of pesticides and the incidence of dermatitis in paddy farmers in Mowewe District in 2017, showed that the statistical test value at a significant level $\alpha<0.05$ was found to have a significant relationship between knowledge and the incidence of contact dermatitis ( $\rho$-value $=0,000)$, there was a relationship meaningful between the types of pesticides with the incidence of contact dermatitis $(\rho$-value $=0.003)$, there is a significant relationship between the dose of pesticides with the incidence of contact dermatitis $(\rho$-value $=0,000)$, there is a significant relationship between the frequency of spraying with the incidence of contact dermatitis $(\rho$-value $=$ 0.001 ) there is a significant relationship between the use of PPE and the incidence of contact dermatitis ( $\rho$-value $=$ $0.002)$ in farmers [9].

Based on some of the results of the research above shows that the application of the use of Pesticides requires special attention in handling and needed a participatory method that involves the community or farmer groups to increase awareness of the use of pesticides and prevent poisoning due to pesticides.

Appropriate Participatory Method to be used is Participatory Rural Appraisal (PRA) because, in essence, PRA is a study that is characterized by the active involvement of the community as a target group to intervene and understand the problems they face, while outsiders position themselves as facilitators in controlling activities, participatory assessment, assessment, research, village conditions [10].

Thus the PRA method is a method used in conducting studies to understand the situation or condition of villages by involving community participation. In addition, the PRA is also a group of approaches and methods that enable village communities and activity groups to share, improve and analyze their knowledge of village conditions and life, make plans and act [11].

East Kolaka Regency in 2018 there were 42 cases of pesticide poisoning by farmers. The highest cases are in the work area of the Puskesmas Ladongi with eight cases, Lalolae two cases, Mowewe four cases, Uluiwoi three cases, Ueesi three cases, Aere four cases, Lambandia five cases, Poly-polia three cases, Loea four cases, Dangia three cases, whereas in Tirawuta Puskesmas there were three cases [12].

Based on the results of the initial survey, obtained information by interviewing rice farmers that they often experience health problems after spraying, such as nausea, headaches, fatigue and weakness, itching, urination disorders at night even among farmers who have experienced poisoning which requires special treatment from health workers. Apart from the farmers' interviews were also conducted with Field Extension Officers (PPL) and Health Officers at the Ladongi Health Center, East Kolaka Regency, and information was obtained that rice farmers often poisoned after spraying.

The use of pesticides in the long term and do not pay attention to the dose of use, personal protective equipment, frequency of spraying, spraying mechanism, personal hygiene and post-spraying when working will have an impact on the health of rice farmers [13].

Farmers' habits in using pesticides tend to ignore the provisions of the use of pesticides, including not using a complete Personal Protective Equipment (PPE); hats, long sleeves, long pants, gloves, masks, and shoes, can affect the health status of farmers [14]. Based on the background description of this research, the purpose of this study was to determine the effect of participatory rural appraisal in increasing the awareness of spraying farmers on the use of personal protective equipment.

\section{Methods}

This type of research is a pre-experimental design with one group design pre-post test. The population in this study is farmers who are members of the Farmers Group Gapoktan Tirtomulyo Ladongi District as many as 240 farmers. The sample size of 148 respondents was taken by simple random sampling. Data obtained using a questionnaire then analyzed descriptively and inferentially using the Mc Nemar test. 


\section{RESULTS}

The Effect of Participatory Rural Appraisal in Increasing Farmers' Awareness of Sprayers on the Use of PPE

The effect of participatory rural appraisal methods to increase awareness of spraying farmers on the use of PPE can be seen in the following table:

Table-1: Participatory Rural Appraisal Increases Farmers' Awareness of Sprayers against the Use of PPE

\begin{tabular}{|c|c|c|c|c|}
\hline Use of PPE Before Intervention & \multicolumn{2}{|c|}{ Use of PPE After Intervention } & Total & $\boldsymbol{p}$ \\
\cline { 2 - 4 } & Less & Good & & \\
\hline Less & 36 & 76 & 112 & \multirow{2}{*}{0,000} \\
\hline Good & 0 & 36 & 36 & \\
\hline Total & 36 & 112 & 148 & \\
\hline
\end{tabular}

Table 1 shows that at the time before the intervention using the participatory rural appraisal method there were 112 respondents whose use of PPE was classified as less, then after the intervention, 36 respondents remained poor and 76 respondents turned out to be good. While of the 36 respondents who used PPE in the good category before the intervention, it remained good after the intervention. Statistical test results using the Mc. Nemar test obtained a p-value of $0,000<\alpha 0.05$, which means participatory rural appraisal can increase farmers' awareness in using personal protective equipment (PPE).

\section{DISCUSSION}

Participatory rural appraisal (PRA) is a group of approaches and methods that enable communities to share, improve and analyze their knowledge of conditions and life in the community, make plans and act[15].

The results showed that at the time before intervention with the participatory rural appraisal method there were 112 respondents whose use of PPE was classified as less, then after the intervention, 36 respondents remained lacking. This is due to the lack of available personal protective equipment in the farmer group, the lack of respondent participation in participating in participatory rural appraisal (PRA) activities, so the understanding of using personal protective equipment is still lacking, and respondents feel uncomfortable working when using personal protective equipment. Lack of awareness of some respondents in using personal protective equipment is due to the habit of carrying out daily protection not to use personal protective equipment.

Another thing that causes no difference between before and after the intervention is the time factor, where the time needed for behavior change turns out to vary, based on Kurt Lewin's behavioral concept it is said that the higher driving forces, in this case, one's intentions can then shorten the time of behavior change. This is supported by Theory of Reasoned Action which says that intention is the main factor for someone to determine behavior to be carried out or not, it is very basic because with the intention the individual is willing to change[16].

And of the 112 respondents who used PPE as less, there were also 76 respondents who turned out to be good. Changes in the practice of the use of personal protective equipment (PPE) among farmers, due to several things including the participatory rural appraisal (PRA) method given, wherein this method the delivery of information is accompanied by demonstrations and examples that can make respondents easy to remember with the material presented and make the atmosphere pleasant because respondents will tend to actively explore the ideas they have so as to increase their motivation, interests, and emotions that have an impact on increasing personal experience. This is in line with research which states that participatory methods can increase community knowledge in remembering or receiving information [17].

Another thing that causes changes in the practice of the use of personal protective equipment is the main aspects highlighted in the participatory rural appraisal (PRA) method, which is community empowerment by generating a spirit and spirit of independence, the involvement of various parties or cross-sectors in various forms of promotion such as community, men, women, parents, children, rich-poor, community leaders, religious leaders, teachers, and local governments, as well as aspects of replication as a result of community pride.

This is in accordance with the theory of behavior change Stimulus-Organism-Response (SOR) which says that the cause of behavior change depends on the stimulus or stimulus provided, in this study the stimulus provided is a participatory rural appraisal (PRA) method about the use of personal protective equipment [18]. 


\section{CONCLUSION}

From the results of the study, it can be concluded that the participatory rural appraisal method can be an alternative method in increasing farmers' awareness of the use of personal protective equipment (PPE). It is hoped that the participatory rural appraisal method can be an alternative method in increasing community participation in the prevention of poisoning due to the use of pesticides for farmers.

\section{REFERENCES}

1. Budiawan, A. R. (2013). Faktor risiko Cholinesterase rendah pada petani bawang merah. KEMAS: Jurnal Kesehatan Masyarakat, 8(2).

2. Agustina, Z. I. N., Tarwaka, P. S., \& Erg, M. (2019). Analisis Paparan Getaran Mekanis terhadap Kondisi Kesehatan Pekerja pada Bagian Produksi di CV. Mulya Abadi Sukoharjo. Thesis, Universitas Muhammadiyah Surakarta.

3. Lesar, F. Y., Joseph, W. B., \& Rattu, A. J. M. (2016). Hubungan Antara Tingkat Pendidikan Dan Pengetahuan Tentang Bahaya Pestisida Bagi Kesehatan Dengan Pengelolaan Pestisida Pada Kelompok Tani Di Kecamatan Belang Kabupaten Minahasa Tenggara. ikmas, 1(7).

4. Herdianti, H. (2018). Hubungan Lama, Tindakan Penyemprotan, Dan Personal Hygiene Dengan Gejala Keracunan Pestisida. PROMOTIF: Jurnal Kesehatan Masyarakat, 8(1), 72-77.

5. Mayasari, D., \& Silaban, I. (2019). Pengaruh Pajanan Organofosfat terhadap Kenaikan Tekanan Darah pada Petani. Agromedicine Unila, 6(1), 186-193.

6. Marsaulina, I., \& Wahyuni, A. S. (2007). Faktor-faktor yang berhubungan dengan keracunan pestisida pada petani hortikultura di Kecamatan Jorlang Hataran Kabupaten Simalungun Tahun 2005. Media Penelitian dan Pengembangan Kesehatan, 17(1).

7. Kurniadi, D. (2018). Faktor-Faktor Yang Berhubungan Dengan Keluhan Kesehatan Akibat Paparan Pestida Pada Petani Hortikultura Di Desa Siulak Deras Mudik Kabupaten Kerinci. Menara Ilmu, 12(80).

8. Mahyuni, E. L. (2015). Faktor Risiko dalam Penggunaan Pestisida pada Petani di Berastagi Kabupaten Karo 2014. Kes Mas: Jurnal Fakultas Kesehatan Masyarakat Universitas Ahmad Daulan, 9(1), 25014.

9. Cisdin, G., \& Lisnawaty A. (2017). Hubungan Penggunaan Pestisida Terhadap Kejadian Dermatitis Kontak Kecamatan Mowewe Kabupaten Kloaka Timur. Jurnal Ilmiah Mahasiswa Kesehatan Masyarakat, 7, $250-731$.

10. de Aguiar, A. L., da Silva, R. R., Alves, S. M., da Silva, L. P., de Morais, O. R., \& Lobo, R. N. B. (2020). Breeding objectives and selection criteria of a participatory community-based breeding programme of goats and sheep. Tropical Animal Health and Production, 1-11.

11. Omondi, L. A. (2020). Learning together: Participatory rural appraisal for coproduction of climate change knowledge. Action Research, 1476750320905901.

12. Health Office of East Kolaka Regency. (2019). Profil Kesehatan Kabupaten Kolaka Timur. Kendari.

13. Annida, S. (2018). Hubungan antara frekuensi dan lama penyemprotan dengan keracunan pestisida pada petani di desa Srikaton Kecamatan Adiluwih Kabupaten Pringsewu. Universitas Lampung.

14. Arika, P. P. (2018). Hubungan Personal Hygiene Dan Penggunaan Apd Dengan Kejadian Dermatitis Pada Petani Padi Di Desa Kebonsari Kecamatan Kebonsari Kabupaten Madiun. STIKES Bhakti Husada Mulia Kota Madiun.

15. Hendrawan, A. H., Maulani, W. D., \& Indriyani, S. (2018). Memberdayakan Dan Membangun Masyarakat Puraseda Melalui Pendidikan Serta Berakhlakul Karimah. Abdi Dosen: Jurnal Pengabdian Pada Masyarakat, 2(4).

16. Murti, B. (2018). Teori promosi dan perilaku kesehatan. Karanganyar: Bintang Fajar Offset.

17. Mangidi, M. A. G. T., Sunarsih, S., \& Jayadipraja, E. A. (2019). Pengaruh Pemicuan Terhadap Angka Bebas Jentik (ABJ) Di Kelurahan Rahandouna Kota Kendari. Al-sihah: The Public Health Science Journal, 11(2).

18. Chen, C. C., \& Yao, J. Y. (2018). What drives impulse buying behaviors in a mobile auction? The perspective of the Stimulus-Organism-Response model. Telematics and Informatics, 35(5), 1249-1262. 